\title{
Beyond beef: dietary variability and foodways in the late 19th-century mining town of Hammondville, New York, USA
}

\author{
Sarah P. SPORTMAN \\ Archaeological and Historical Services, Inc., \\ 569 Middle Turnpike Road, \\ Storrs, Connecticut, 06268 (USA) \\ sarahsportman@gmail.com
}

KEY WORDS

Zooarchaeology,

faunal analysis, historical archaeology, foodways, ethnicity.

\begin{abstract}
Sportman S. P. 2014. - Beyond beef: dietary variability and foodways in the late 19th-century mining town of Hammondville, New York, USA, in Thomas R. \& Fothergill B. T. (eds), Animals, and their Bones, in the 'Modern' World (AD 1750-1900). Anthropozoologica 49 (1): 63-78. http://dx.doi.org/10.5252/az2014n1a05.
\end{abstract}

\section{ABSTRACT}

This study employs a combination of historical documents and faunal remains to examine food procurement strategies, purchasing patterns and foodways among the residents of Hammondville, a late 19th-century, multi-ethnic, company-owned mining town located in the Adirondack region of eastern upstate New York (USA). The Crown Point Iron Company (C.P.I.Co.), which operated the only store in the village, controlled both peoples' incomes and the types of food available for purchase. Despite this, analysis of company store records and zooarchaeological data suggest that individuals and families from different backgrounds worked within the structures of company control to construct diets that met their subsistence needs and expressed their cultural identities. They accomplished this by selectively utilising the store inventory and by supplementing store-bought foods through fishing, hunting and raising small numbers of domesticated animals.

\section{RÉSUMÉ}

Au-delà du boeuf: variabilité diététique et alimentation dans la ville minière de Hammondville, New York, État-Unis, à la fin du XIXe siècle.

Cette étude emploie une combinaison de documents historiques et de restes fauniques pour examiner les stratégies d'approvisionnement alimentaire, les schémas d'achats et les pratiques alimentaires parmi les résidents de Hammondville, une ville minière multi-ethnique de la fin du xixe siècle détenue 
MOTS CLÉS

Archéozoologie, analyse faunique, archéologie historique, habitudes alimentaires, origine ethnique. par la société Crown Point Iron Company (C.P.I. Co.), située dans la région des Adirondack à l'Est du Nord-Ouest de l'état de New York (Upstate New York, États-Unis). La C.P.I. Co. opérait le seul magasin du village, contrôlant de ce fait à la fois le revenu de ses habitants et le type de nourriture qui leur était possible d'acheter. Malgré tout, une analyse des registres du magasin de la C.P.I. Co. et des données zooarchéologiques suggère que les individus et les familles de différentes origines œuvraient à l'intérieur des structures de contrôle de la compagnie pour construite des diètes qui, à la fois, rencontraient leurs besoins de subsistance et exprimaient leurs identités culturelles. Pour ce faire, ils utilisaient l'inventaire du magasin de façon sélective et supplémentaient les aliments commerciaux avec les produits de la pêche, de la chasse, et de l'élevage d'un petit nombre d'animaux domestiqués.

\section{INTRODUCTION}

Ethnicity is a key aspect of social relations in culturally diverse communities. Food is a powerful symbol people employ in the construction and expression of ethnicity, because it is an intrinsic and often conservative aspect of identity (Reitz 1991). Evidence of peoples' attempts to maintain traditional diets in contexts of cultural change has been recovered archaeologically in the form of food-related material culture and faunal and botanical remains (Janowitz 1993; Lightfoot et al. 1998; McBride 2007; Milne and Crabtree 2001).

Although the purchase, preparation and consumption of food are mundane activities, they are also meaningful, because people are aware of the symbolic nature of food and utilise it in their daily lives (Camp 1989: 29). Traditional foods and ways of eating link people to the past. The preparation and consumption of certain foods, particularly those associated with ethnic or religious traditions, symbolise shared identity and group membership. Used in this way, food brings people together and reinforces the shared history of a group. At the same time, such practices separate a group from 'others' who do not eat the same foods and do not share their history.

This study employs a combination of historical documents and faunal remains to examine the differences in purchasing patterns, food procurement strategies and foodways among the residents of
Hammondville, a late 19th-century, multi-ethnic, company-owned mining town located in the northeastern Adirondack Mountains, New York (USA). At Hammondville, the Crown Point Iron Company (C.P.I.Co.) owned and operated the only store. As a result, the company largely controlled the commercial food procurement system in the village and most Hammondville residents had a limited range of food options. However, surviving company store ledgers, which provide a record of the types and quantities of foods purchased by Hammondville residents, suggest that although people from different cultural backgrounds relied on many of the same dietary staples, they often preferred different types of foods and selectively purchased those foods when they were available.

Company store records also provide an important baseline for comparison with the archaeological record. By comparing the store inventory of meats to the types of animal remains recovered archaeologically from occupation sites in the village, it is possible to identify other means of food procurement utilised by Hammondville residents. Such activities enabled villagers to reduce the amount of their income spent at the company store and to procure foods that were not available for sale. Taken together, the analyses presented here shed light on the ways people adapted to life in a company-controlled town by working within the structures of company control to construct diets that both met their subsistence needs and express their cultural identities. 


\section{BACKGROUND TO THE RESEARCH}

Hammondville was established in 1873 by the C.P.I.Co. as a hamlet of Crown Point, New York (Fig. 1). Starting in 1872, the company rapidly expanded: it intensified its iron-ore mining and processing enterprises and greatly increased the size of its workforce. Hammondville was built to house the resulting influx of workers and their families. The village site was chosen for its proximity to the C.P.I.Co.'s mines and Hammondville was literally built up around the mining operation. The company built single-family homes for management, multifamily tenements and double houses for workers with families, boarding houses for single men, a church, a school, a doctor's office and a store.

Named after company president and local Civil War hero Gen. John Hammond, Hammondville was truly a 'company town'. The village was designed according to the structuring principles of 19thcentury industrial capitalism. Similar 'landscapes of inequality', created to reinforce and reproduce status and rank, were built into company towns across the United States during this period (Crawford 1995; Garner 1992; McGuire 1991; Mrozowski 1991). The C.P.I.Co. owned all land, buildings and transportation routes (Bixby 1911), required workers to live in company housing and provided most of the amenities of daily life, including the only store (Plattsburgh Sentinel 1874). Additionally, C.P.I.Co. management comprised wealthy, American-born Protestants who emphasised their values through company policies. They established rules governing moral behaviour, actively supported Protestant Christian services, organisations and activities and enacted paternalistic policies designed to transform the working-class immigrant labourers into moral, temperate and productive Americans (Sportman 2011).

Census data indicate that the majority of residents were first or second generation immigrants from England, Ireland, Quebec and Sweden, although many native-born Americans also lived and worked in the village (Fig. 2). Historical research, based on primary documents and contemporary newspaper accounts of village life, suggests that at Hammondville, nationality was a key aspect of ethnic identities and social organisation. Hammondville residents regularly seg-

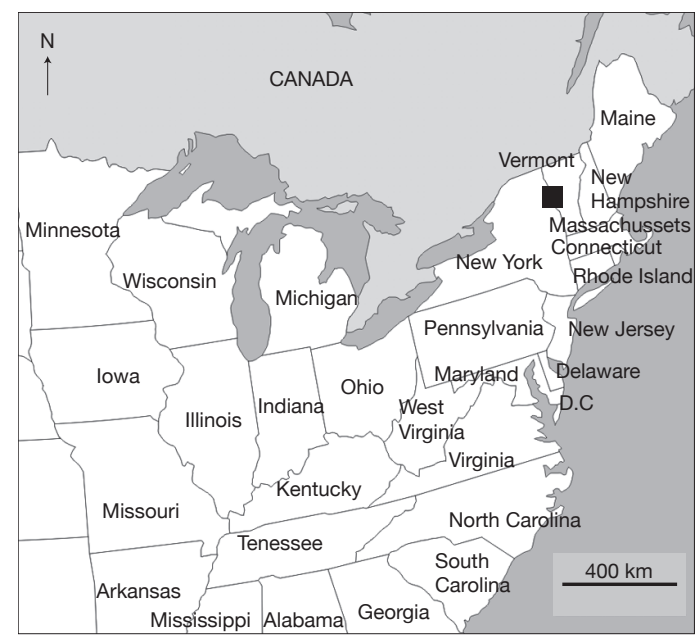

FIG. 1 - Site location: Hammondville, Crown Point, New York.

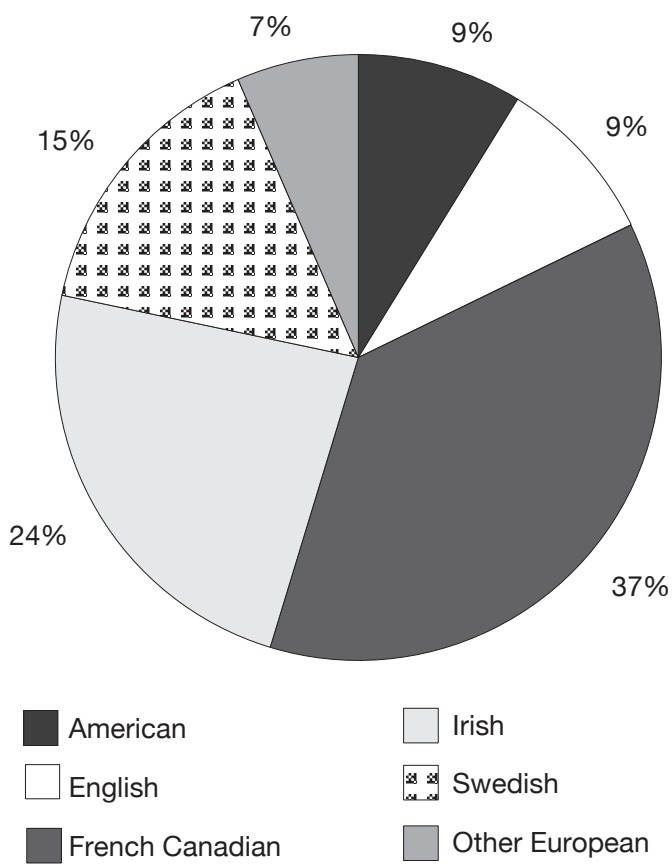

Fig. 2. - Composition of the C.P.I.Co. workforce c.1880 (United States Bureau of the Census 1880).

regated themselves, primarily working, worshipping, marrying, boarding and socialising with those who shared the same backgrounds and cultural values. In 


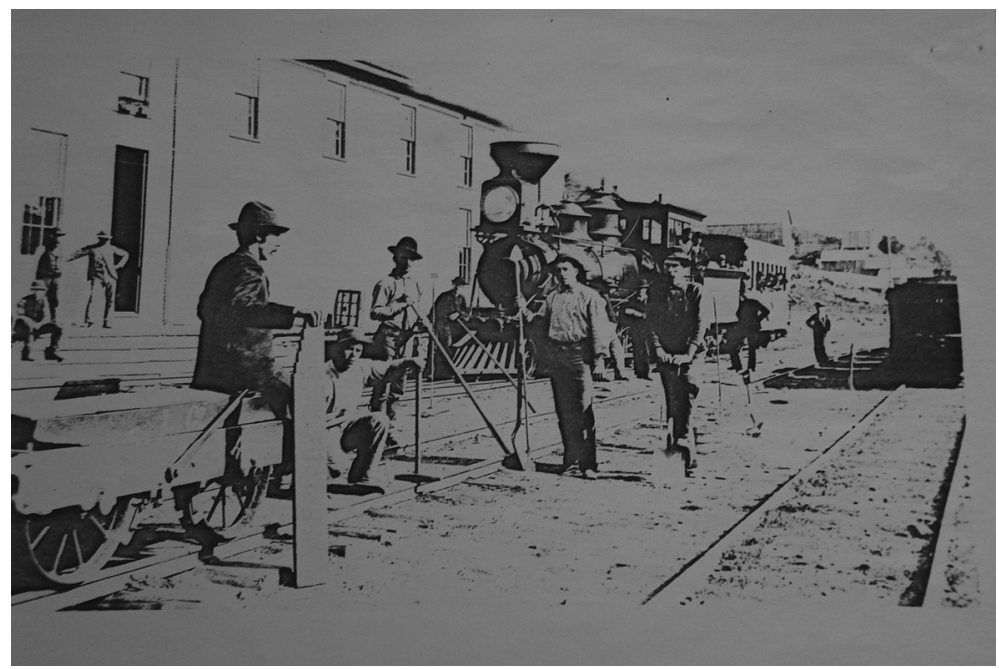

Fig. 3. - The company store at Hammondville. Photograph by Seneca Ray Stoddard c.1878, used with the permission of the Penfield Foundation, Ironville, New York.

this way, villagers established strong social networks and reinforced their ethnic identities within the larger Hammondville community (Sportman 2011)

Hammondville and the expanded C.P.I.Co. were both relatively short-lived. Although the company was profitable during the 1870 s and early 1880 s (Hammond 1884), a combination of national economic conditions, competition and exhausted ore supplies led to its collapse in the 1890s (Northey 1940). In 1896 the C.P.I.Co. dissolved officially (Elizabethtown Post and Gazette 1896). The next year the company and all of its holdings were sold to the American Steel and Wire Company. By 1900, most remaining residents of Hammondville had abandoned the village and the buildings, equipment and architectural materials were auctioned off to resolve company debts (Elizabethtown Post and Gazette $1900 \mathrm{a}, 1900 \mathrm{~b})$. The village was literally dismantled, leaving only foundations and cellar holes at the site.

\section{THE HAMMONDVILLE COMPANY STORE}

At Hammondville, the company store served as both an obvious symbol of company control and a way to generate significant revenue to supplement the
C.P.I.Co.'s mining and iron-processing operations By 1876 , the store, which took in profits of as much as $\$ 3000$ a day, had outgrown its original building and the company built a new, larger structure (Pope 1971:40). The new building, which housed both the store and the company's offices, was located in the bustling centre of Hammondville (Fig. 3).

Due to both geographic and economic factors, most Hammondville residents relied heavily on the company store to meet their subsistence needs. Although Hammondville was not completely isolated (it was connected to other settlements by wagon roads and the C.P.I.Co. railroad), even the closest villages were several miles away. Additionally, C.P.I.Co. labourers could purchase food and other goods at the company store against their wages or on credit. In difficult financial times, the company also sometimes paid their employees in store credit in lieu of cash wages (Ticonderoga Sentinel 1874). These factors limited the ability of most Hammondville residents to purchase food elsewhere.

As a result of this situation, the Hammondville company store provides a well-controlled test case for analysing differences in purchasing patterns among people of different backgrounds. Because all villagers had access to the same inventory, any differences in purchasing patterns will necessar- 
TABLE 1. - Average per household food purchases, calculated from the 1882-1883 C.P.I.Co. store ledger.

\begin{tabular}{lcccccc}
\hline Item & Unit & $\begin{array}{c}\text { French } \\
\text { Canadian }\end{array}$ & Swedish & Irish & English & American \\
\hline beef & Ibs. & 38.75 & 67.82 & 58.62 & 112.41 & 45.34 \\
roast & Ibs. & 17.89 & 37.78 & 46.75 & 55.92 & 26.82 \\
steak & Ibs. & 9.48 & 9.33 & 42.75 & 53.89 & 24.55 \\
veal & Ibs. & 0.14 & 0.00 & 0.30 & 1.61 & 1.61 \\
shank & each & 1.00 & 1.82 & 0.47 & 0.19 & 0.73 \\
pork & Ibs. & 46.73 & 16.61 & 22.72 & 39.92 & 24.32 \\
pig feet & Ibs. & 0.95 & 0.52 & 0.33 & 0.69 & 0.52 \\
pig head & Ibs. & 1.52 & 2.83 & 3.97 & 1.30 & 0.64 \\
sausage & Ibs. & 0.74 & 0.79 & 3.83 & 4.56 & 2.73 \\
mutton & Ibs. & 0.30 & 0.38 & 0.15 & 6.39 & 1.18 \\
goose & Ibs. & 0.31 & 0.24 & 0.00 & 0.47 & 0.00 \\
turkey & Ibs. & 1.33 & 0.54 & 0.77 & 1.34 & 1.70 \\
head cheese & Ibs. & 0.30 & 2.13 & 0.57 & 0.61 & 0.68 \\
souse & Ibs. & 0.00 & 0.29 & 0.00 & 0.53 & 0.00 \\
cabbages & head & 1.03 & 1.04 & 3.47 & 1.25 & 1.36 \\
onions & bushel & 0.19 & 0.04 & 0.32 & 0.80 & 0.11 \\
potatoes & bushel & 2.16 & 0.03 & 1.73 & 0.91 & 0.61 \\
apples & bushel & 0.16 & 0.01 & 0.15 & 0.01 & 0.05 \\
\hline
\end{tabular}

ily be expressed in terms of what people chose to purchase from among the store offerings. The first part of this study employs company store records to compare the purchasing patterns of Hammondville residents of different backgrounds in order to shed light on the ways people utilised the available store inventory to meet their dietary needs and express their cultural identities.

\section{COMPANY STORE RECORDS AND DIETARY VARIABILITY}

Surname-specific C.P.I.Co. store records were examined to explore the ways Hammondville residents utilised the inventory of foods available at the company store. Several years worth of C.P.I.Co. ledgers survive in the archives of the Penfield Foundation in Ironville, New York. The ledgers are hand-written and each includes several hundred pages of entries covering five to six months of sales. For reasons not understood, the ledgers record purchases from every other month. The 1882-1883 ledger discussed in detail here contains over 2,000 entries from August, October and December of 1882, and February and April of 1883. The record of each transaction includes the buyer's name, the item, the quantity of the item purchased, the cost per unit (e.g. pound, dozen, bushel) and the total price of the purchase. All of the names listed in the ledger are those of male employees of the C.P.I.Co. It is likely, however, that women made most of the purchases. The men's names were probably listed to simplify bookkeeping, as they were the ones drawing wages from the company.

The 1882-1883 ledger was transcribed in its entirety because it covered a period in the middle of Hammondville's heyday, between 1873 and 1893, when the population was largest. Analysing a period covering several months' worth of food purchases is important, because food-purchasing decisions are often short-term economic decisions based on shortterm economic conditions (Huelsbeck 1991) and seasonal availability. Examining the purchases made over a long period of time therefore provides a more accurate representation of food purchasing strategies.

Names in the ledger were cross-referenced with contemporary New York State and U.S. Federal Manuscript Censuses and Crown Point vital records to establish the nationalities of the people recorded. As noted above, nationality was a key aspect of ethnic identities and social relations at Hammondville. Over 75\% ( $\mathrm{n}=99)$ of the people listed were identified and this analysis includes only those individuals. Identified store pa- 


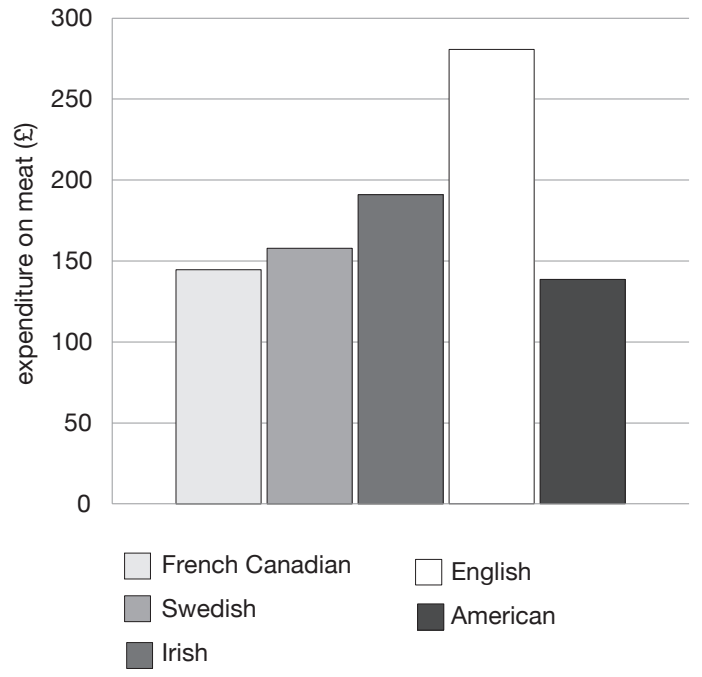

Fig. 4. - Total average per household meat purchases in pounds, based on the 1882-1883 C.P.I.Co. store ledger.

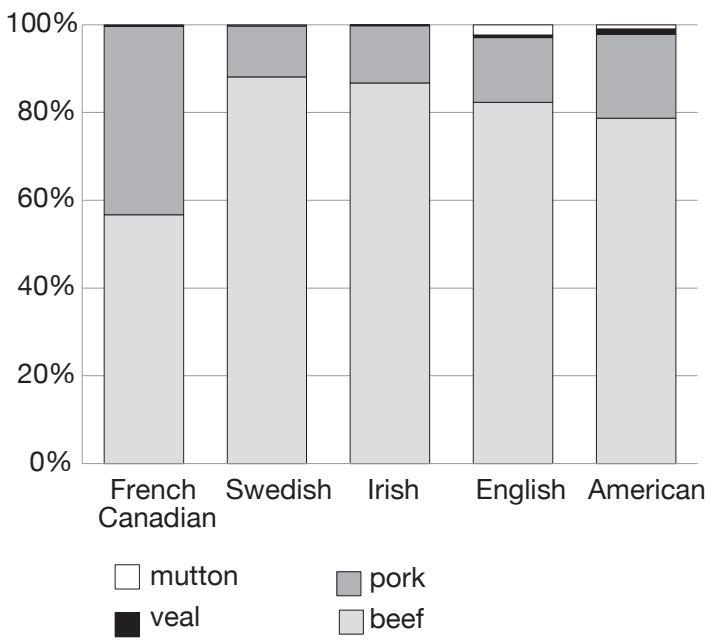

FIG. 5. - Relative proportions of major meat types (beef, pork, mutton and veal) purchased by each group, based on the 18821883 C.P.I.Co. store ledger.

trons included 29 French Canadians, 28 Swedes, 15 Irish, 16 English and 11 Americans. The food items included categories simply labelled 'beef' and 'pork' which likely included both fresh and preserved cuts, as well as cuts specified as beef steaks, roasts and shanks, veal, pigs' feet and heads, pork sausage, mutton, goose and turkey (only for Christmas), head cheese (a meat jelly made using meat from the head of a calf or pig) and souse (head cheese pickled in vinegar). A small variety of storable produce, such as cabbages, onions, potatoes and apples were also sold, but this study only addresses meat purchases.

To analyse the data in the store records, it was necessary to standardise the quantities of food purchased (Table 1). This was accomplished by calculating the average per household purchases of each item for each group. First, the total quantity of each type of food purchased by the identified American, English, Irish, French Canadian and Swedish consumers was calculated. That number was then divided by the number of individuals recorded for each group. For example, Irish consumers purchased a total of $641.25 \mathrm{lb}$ of beef steak during the period under study. When divided by the 15 Irish consumers listed in the ledger, the result is an average of $42.75 \mathrm{lb}$ of steak per household. This method enables a calculation of the dietary composition of each group and permits comparisons between and among the different groups.

\section{PURCHASING PATTERNS AND DIETARY COMPOSITION}

Company store records, examined within the context of the purchasers' nationalities, provide clear evidence of differences in purchasing patterns and dietary composition, discussed in detail below, primarily relating to the quantities of meat, types of meat and cuts of beef purchased.

\section{QUANTITIES AND TYPES OF MEAT}

The average per household purchases of total pounds of meat varied significantly among the different groups at Hammondville $\left(\chi^{2}=11.75, \mathrm{df}=4, \mathrm{P}<0.02\right)$. On average, English consumers purchased the most meat (280.64lbs), followed by Irish (191.06lbs), Swedish (157.86lbs), French Canadian (144.64lbs) and American consumers (138.59lbs) (Fig. 4).

An examination of the major types of meat sold at the store, which include beef, pork, mutton and veal, suggests several key similarities and differences in the diets of different groups (Fig. 5). Overall, beef 
was the most common meat in the diet, followed by pork, then mutton and veal. This is largely attributable to the availability of these foods at the company store. Beef was the most common meat in the store inventory and was always available. Pork was also often available, but mutton and veal were seasonal and stocked in much smaller quantities. Beef comprised similar proportions of Swedish (88.1\%), Irish (86.7\%), English (82.3\%) and American $(78.7 \%)$ meat purchases. The average French Canadian diet, however, included only $56.7 \%$ beef; thus while it remained the most common meat, it comprised a significantly smaller proportion of the diet than it did among the other groups. Based on store records, the French Canadian diet included a significantly larger proportion (42.9\%) of pork. Americans consumed the second largest proportion of pork (19.1\%), followed by the English (14.7\%), Irish (13\%) and Swedish (11.6\%).

Mutton, the third most common meat, comprised only a small proportion of the diets of each group. It made up $2.4 \%$ of the meat in the English diet, $0.9 \%$ in the American diet, $0.3 \%$ in the Swedish diet, $0.2 \%$ in the French Canadian diet and only $0.08 \%$ of meat in the Irish diet. While the relative proportions of mutton in the diet of each group is small, it is important to note that English households consumed a much larger proportion than all other groups. In fact, English consumers purchased over $75 \%$ of all of the mutton sold at the company store. This suggests that although mutton did not make up a large part of their overall diet, it was a preferred food and English consumers actively sought it out and purchased it when it was available. Finally, veal, which was only seasonally available, comprised a very small proportion of the diets of each group. The American diet included the largest proportion of veal (1.2\%), followed by English (0.6\%), Irish $(0.2 \%)$ and French Canadians (0.1\%). No veal was purchased by Swedish households.

Other types of meat, which were stocked and sold less frequently than beef, pork, mutton and veal, also provide information about food preferences and dietary composition. 'Other meats' include sausage, headcheese, souse, pigs' feet and heads, goose and turkey. Taken together, these items comprise less than $5 \%$ of the overall meat in the diets of each

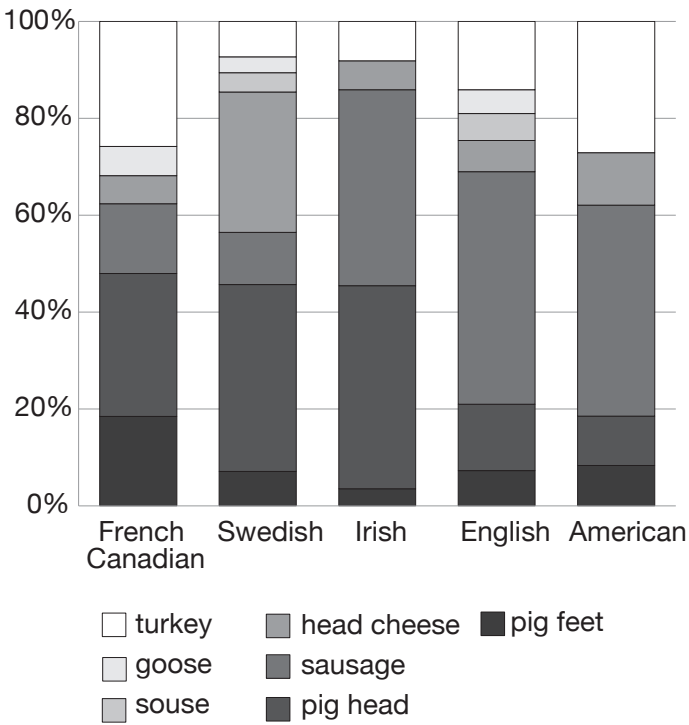

FIG. 6. - Relative proportions of 'other meats' purchased by each group, based on the 1882-1883 C.P.I.Co. store ledger.

group, but there are important differences in relative abundance (Fig. 6). Sausage, which was only seasonally available, comprised similar proportions of English (48\%), American (43.5\%) and Irish $(41.9 \%)$ 'other meat' purchases. This suggests that sausage was a preferred food among these groups. French Canadian and Swedish diets included much smaller proportions of sausage ( $14.4 \%$ and $10.8 \%$, respectively).

Clear differences also exist in the relative proportions of headcheese and souse in the diets of different groups. Headcheese comprised a much larger proportion of 'other meats' in the Swedish diet (29\%). Americans consumed the second largest proportion of headcheese $(10.8 \%)$, followed by English (6.4\%), Irish (6\%) and French Canadians (5.8\%). Souse, which is a similar type of cold cut, was less commonly available in the store inventory and was only included in the diets of English (5.6\%) and Swedish (4\%) households. Headcheese was traditionally an important item in Swedish foodways (Kaplan 1986; Larson and Barton 1987) and it is clear that Swedish families at Hammondville continued to include headcheese in their diets when possible. 


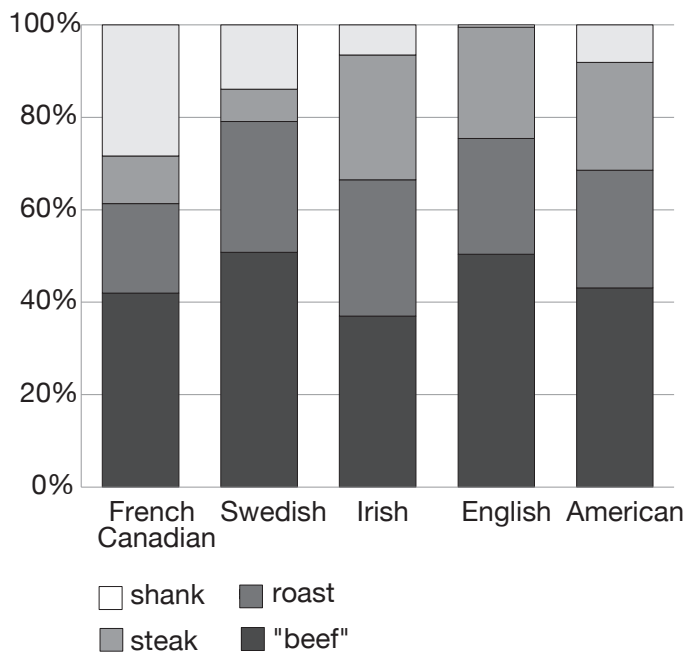

FIG. 7. - Relative proportions of different cuts of beef purchased by each group, based on the 1882-1883 company store ledger.

Pigs' feet and heads were also sometimes available for sale at the company store and all groups included both items in their diets. Pigs' feet comprised $18.4 \%$ of the 'other meats' in the French Canadian diet, 8.3\% in the American diet, $7.3 \%$ in the English diet, $7.1 \%$ in the Swedish diet and 3.5\% in the Irish diet. While the Irish diet included the smallest overall proportion of pigs' feet, it included the largest proportion $(41.9 \%)$ of pigs' head, followed by Swedes (38.6\%), French Canadians (29.5\%), English (13.7\%) and Americans (10.2\%).

Finally, the company store also sold goose and turkey, but they were only available in the weeks leading up to Christmas. Turkey was more popular and was purchased by members of all groups, while only French Canadian, Swedish and English consumers purchased geese. Turkey comprised $27.1 \%$ of the 'other meats' purchased by Americans, followed by $25.8 \%$ of those purchased by French Canadians, $14.1 \%$ by English, $8.1 \%$ by Irish and $7.4 \%$ by Swedish consumers. These sales suggest aspects of the holiday foodways practiced by each group. Holidays are often times when people adhere most strongly to culinary traditions. This suggests an interesting line of future research using the available store ledgers from Hammondville. A focus on the store inventory and food purchases around important holidays may shed light on the ways people maintained aspects of their traditional holiday fare or adapted it to the available food supply at in the village.

\section{CuTs of BeEF}

As discussed above, beef was the most important meat in the diet of people of all of backgrounds at Hammondville, but clear differences exist in the relative proportions of the different cuts of beef purchased and consumed by people of different backgrounds. In addition to meat listed only as beef, which likely encompasses different cuts of both preserved and fresh meat, the company store sold three distinct cuts: steaks; roasts; and shanks. The data presented in Figure 7 indicate some clear differences in the cuts of beef purchased by each group.

English beef purchases included 50.3\% beef, 25\% roasts, $24.2 \%$ steaks and only $0.5 \%$ shanks, suggesting that English households at Hammondville rarely consumed shank cuts, while they ate steaks and roasts in relatively equal proportions. Irish and American households exhibit very similar purchasing patterns in terms of cuts of beef. Like the English, their purchases were dominated by the general 'beef' category (37\% and $44.7 \%$, respectively). Both groups preferred roasts (29.5\% and $26.4 \%$, respectively) and steaks (27\% and $24.2 \%$, respectively) over shanks (6.5\% and $4.7 \%$, respectively), but they consumed relatively more shank cuts than English households. French Canadian and Swedish households exhibited very different patterns. Purchases in the general 'beef' category dominated in both groups $(50.8 \%$ among Swedes and $41.9 \%$ among French Canadians). Both groups also purchased more roasts $(23.6 \%$ and $30 \%$, respectively) than steaks or shanks and both consumed similar proportions of steaks and shanks. French Canadians purchased $12.8 \%$ shanks and $12.5 \%$ steaks, while Swedish consumers purchased $8.6 \%$ shanks and $7.4 \%$ steaks.

\section{DISCUSSION: ETHNICITY, FOODWAYS AND DIET}

The data presented above demonstrate clear differences in the ways households of different cultural backgrounds utilised the company store inventory 
to construct their diets. However, the role of these patterns in ethnic foodways can be clarified if they are also shown to reflect aspects of the traditional diets or preferred foodways. To examine this possibility, the purchasing patterns identified above are compared with historic and ethnographic accounts of contemporary French Canadian, Swedish, Irish, English and American foodways.

First, the relatively large quantities of meat purchased by all groups is likely attributable to the ready availability of meat in the Hammondville company store. The ability to regularly include meat in their diets must have been appealing to those who did not have easy access to it in the past. The dominance of beef in all diets is notable, as historical and ethnographic sources suggest that beef was a common and preferred meat in traditional American and English diets, but not in contemporary French Canadian, Swedish and Irish diets (Beeton 1861; Brault 1986; Bureau of Statistics of Labor 1886; Diner 2002; Henderson 1877; Kaplan 1986; Larson and Barton 1987; Miner 1939; Spencer 2003). This suggests that the constant availability of beef in the company store inventory significantly impacted the dietary composition and foodways of these groups at Hammondville.

\section{French CANADIANS}

French Canadians at Hammondville generally used the company store inventory in ways that fit with data from historic and ethnographic sources. The comparatively small quantities of meat purchased by French Canadians may be partially attributed to their adherence to Catholic fast days. Traditionally, Catholics were expected to refrain from eating meat on Fridays and on several other holy days during the year. On fast days, it was appropriate to eat fish, but none is listed in the store ledgers. If French Canadians at Hammondville ate fish, they must have procured it through other means. As expected, pork comprised a large portion of the French Canadian diet, although beef was clearly a staple. Soups were an important part of traditional French Canadian cuisine and relatively large quantities of moderately priced beef and shank cuts may have been used for this purpose.

\section{SWEDISH}

Swedish purchases at the company store fail to meet many of the expectations generated from historic and ethnographic sources. Traditionally meat played a secondary role in the Swedish diet; grains were the staple. As no records of grain purchases are known to exist, it is impossible to address this aspect of the Swedish diet. In general, however, it appears that Swedish households at Hammondville consumed a relatively large quantity of meat, primarily beef. It is somewhat surprising that Swedes purchased relatively little pork and few potatoes. Traditionally, pork and fish were the more important meats in Swedish cuisine and potatoes were a staple. However, several aspects of the Swedish diet at Hammondville seem to fit with accounts of traditional foodways. For example, soups were an important aspect of contemporary Swedish cuisine and the relatively large quantities of moderately priced beef and large number of shanks purchased may have been used to make soups. One late 19th-century Swedish English cookbook states that beef shanks were also the preferred cut for making traditional Swedish meatballs (Anon 1897: 29). Additionally, headcheese was a traditionally favoured food and Swedes purchased more than any other group at Hammondville. They also purchased relatively large quantities of souse, which is similar to headcheese. Finally, Swedish consumers bought the second largest quantity of pigs' heads, which may have been used to make soups or headcheese at home.

\section{IRISH}

Historic and ethnographic sources provide very little solid information about the foodways of Irish immigrants. Nonetheless, some aspects of Irish purchasing patterns meet expectations, while others are surprising. The relatively large quantities of meat in general and beef in particular, are somewhat surprising. Both before and during the Irish famine, meat was not a prominent part of the Irish diet. Cuisine revolved around potatoes, butter and milk. Meat, when available, was generally prepared in soups or stews (Diner 2002; Spencer 2003). Therefore, the heavy use of beef suggests that after the Irish immigrated to America, new foods, which in many ways mirrored the eating habits of 


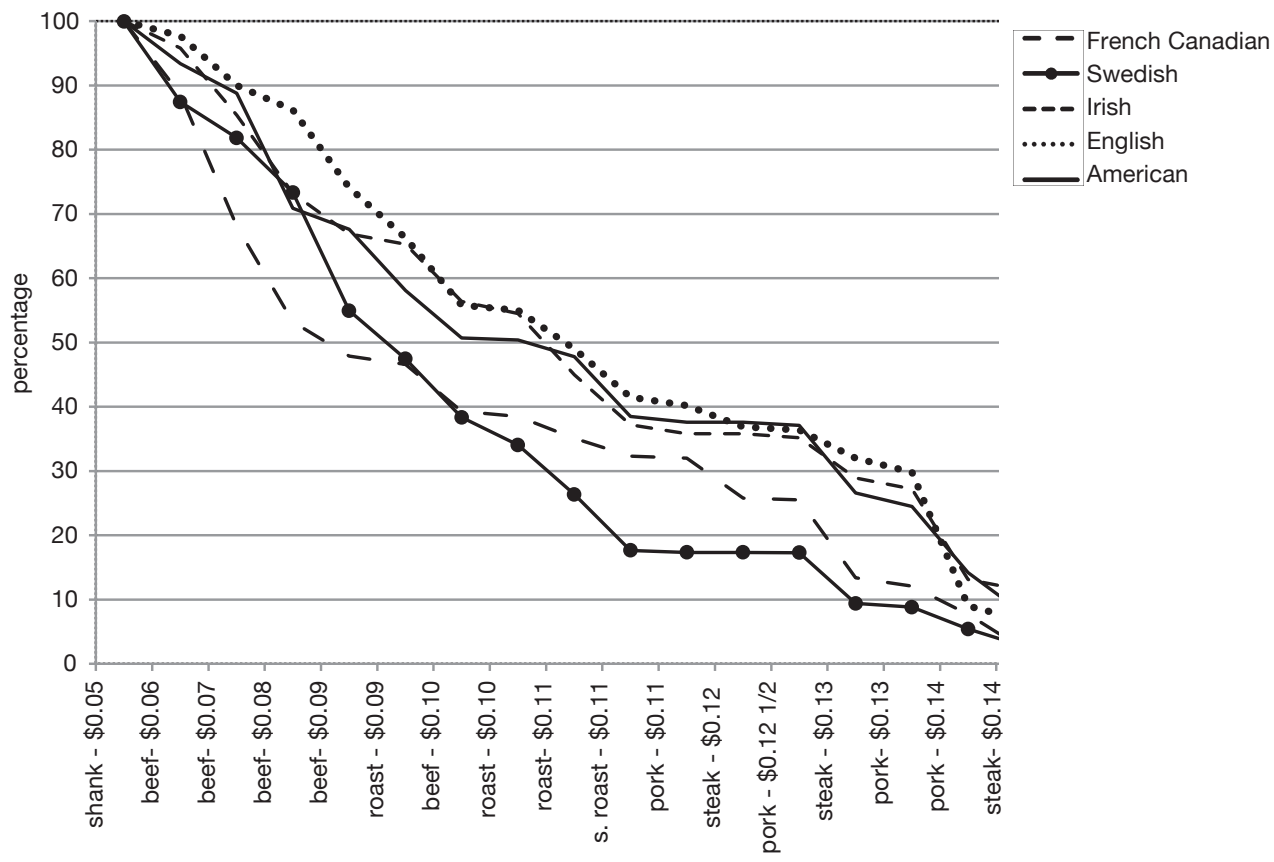

FIG. 8. - Meat cut/type purchases by nationality, presented as cumulative frequency curves; cuts/types are ranked by ascending value.

contemporary Americans, were integrated into their foodways. Overall, the Irish and American diets at Hammondville appear to have been quite similar. This suggests that Irish families had largely adopted American foodways. This is not really surprising for two reasons. First, many of the Irish families at Hammondville came to America in the 1850s and had therefore been in the country for several decades by the 1880s. Second, many famine-era Irish did not have strongly entrenched foodways because of the overall dearth of food in Ireland (Diner 2002).

\section{ENGLISH}

English use of the company store inventory generally fit the expectations generated from historic sources, but there are some surprises. The English diet traditionally relied heavily on meat in general and beef in particular, which is supported by meat purchases at Hammondville (Beeton 1861; Henderson 1877; Spencer 2003: 272-280). Pork was generally eaten in smaller quantities than mutton, veal or lamb, but the store ledger indicates that pork comprised a relatively large proportion of the English diet. This may be attributed to two factors. The first is availability: as noted above, the company store sold mutton and veal less commonly than pork. When mutton and veal were available, it appears that English consumers made the most of the opportunity to purchase them. The second factor contributing to the purchase of relatively large quantities of pork may be the rural location of Hammondville. Although some contemporary cookbooks cautioned against purchasing pork in urban areas, it was believed to be more wholesome in the country (Henderson 1877).

\section{AMERICAN}

American use of the company store generally supports previously generated expectations about foodways. They bought more beef than other meats and purchased a variety of other meats. Because American foodways relied very heavily on meat, however, the relatively small quantities they purchased were somewhat surprising and require explanation. It is 
entirely possible that Americans had greater access to outside sources of food than other groups at Hammondville. Most of the Americans employed by the C.P.I.Co. were born and raised locally and many had family nearby. Additionally, many young American males who worked for the C.P.I.Co. were the sons of local farming families and may have had access to the products of their families' labours.

It is, of course, important to ascertain that the apparent patterns in food purchases discussed above are truly related to cultural preferences and not to economic differences that may have existed between different groups at Hammondville. One way to accomplish this is to examine the relative frequencies of differently priced cuts purchased by people from different backgrounds. Schulz and Gust (1983) utilised this method to examine the frequencies of ranked cuts of meat consumed at four sites in 19th-century Sacramento. Here, instead of zooarchaeological data, documented evidence of purchases and prices are analysed. As discussed above, different cuts of meat like beef, steaks, roasts and pork, were sold for a variety of prices at the store in Hammondville. For instance, items designated simply as beef in the store ledger sold for $\$ 0.06 / \mathrm{lb}$., $\$ 0.07 / \mathrm{lb}$., $\$ 0.08 / \mathrm{lb}, \$ 0.09 / \mathrm{lb}$. and $\$ 0.10 / \mathrm{lb}$. This suggests that the headings 'beef', 'roast', 'steak' and 'pork' encompassed a variety of cuts and qualities. Based on this information, it is therefore possible to rank different food items sold at the company store by cost and then compare the percentages of each purchased by people from different backgrounds. This makes it possible to determine if individuals from particular groups purchased significantly larger proportions of higher or lower cost items, and in turn reveal whether purchasing patterns were influenced by economic constraints rather than cultural preferences.

Figure 8 illustrates the cumulative frequency curves of standardised per-household purchases of differently priced cuts of beef and pork among the French Canadian, Swedish, Irish, English and American households listed in the 1882-1883 company store ledger. While a visual inspection of the curves suggests that some differences existed in the purchasing patterns of people of different ancestries, pair-by-pair comparison of these curves, using a
TABLE 2. - Results of a one-tailed, Kolmogorov-Smirnov two-sample test comparing the cumulative frequency curves of ranked cuts of meat purchased by people of different nationalities.

\begin{tabular}{lcc}
\hline & D & P \\
\hline French Canadian and Swedish & 0.24 & 0.67 \\
French Canadian and Irish & 0.29 & 0.39 \\
French Canadian and English & 0.29 & 0.39 \\
French Canadian and American & 0.29 & 0.39 \\
Swedish and Irish & 0.41 & 0.08 \\
Swedish and English & 0.41 & 0.08 \\
Swedish and American & 0.35 & 0.19 \\
Irish and English & 0.18 & 0.93 \\
Irish and American & 0.18 & 0.93 \\
English and American & 0.12 & 1.00 \\
\hline
\end{tabular}

one-tailed, Kolmogorov-Smirnov two-sample test indicate that these differences are not significant $(P>0.05)$ (Table 2).

These data suggest that economic differences among different nationalities at Hammondville did not play a large role in the price and quality of the different cuts of beef and pork people chose to purchase from the company store. If economic constraints did not result in significantly different purchasing patterns, the idea that cultural preferences played an important and perhaps definitive role in the types and cuts of meat people purchased is strengthened.

\section{ARCHAEOLOGICAL EVIDENCE OF FOOD PROCUREMENT}

The second part of this study combines data from the company store ledgers with faunal remains excavated from two domestic sites in the village. While it is expected that the majority of Hammondville residents purchased most of their food from the company store, a comparison of store records and faunal remains can shed light on whether they were totally dependent upon the company store for food or if they supplemented their diets through other means. Botanical and faunal evidence from other 19th and early 20th century company towns suggests people commonly planted gardens and raised small numbers of domesticated animals to supplement their diets (Gradwohl and Osborn 1984; McGuire 
TABLE. 3. - Taxonomic representation at Long Row 2 and StantonO'Rourke.

\begin{tabular}{lccccc}
\hline Edible Taxa & \multicolumn{2}{c}{$\begin{array}{c}\text { Stanton- } \\
\text { O'Rourke }\end{array}$} & & \multicolumn{2}{c}{ Long Row 2 } \\
\cline { 2 - 3 } \cline { 5 - 6 } & NISP & $\%$ & & NISP & \% \\
\hline Cattle & 191 & 33.6 & & 86 & 30.3 \\
Pig & 22 & 3.8 & & 8 & 2.8 \\
Sheep/goat & 7 & 1.2 & & 4 & 1.3 \\
White-tailed deer & 0 & 0.2 & & 2 & 0.7 \\
Rabbit & 11 & 1.9 & & 0.4 \\
Hare & 1 & 0.2 & & 0 & 0 \\
Lage mammal & 80 & 14.1 & & 67 & 23.6 \\
Medium mammal & 186 & 32.7 & & 85 & 29.9 \\
Small mammal & 16 & 2.8 & & 19 & 6.7 \\
Chicken & 35 & 6.1 & & 4 & 1.5 \\
Turkey & 5 & 1.2 & & 1 & 0.4 \\
Duck & 0 & 0 & & 2 & 0.7 \\
Pigeon family & 1 & 0.2 & & 0 & 0 \\
Pheasant family & 4 & 0.7 & & 4 & 1.4 \\
Perch & 3 & 0.5 & & 0 & 0 \\
Cod family & 7 & 1.2 & & 0 & 0 \\
Salmon family & 0 & 0 & & 1 & 0.4 \\
\hline
\end{tabular}

1991; Mrozowski et al. 1996). Such activities permit more autonomy in food choice (McKee 1987) and may better reflect food preferences than store-bought items. Additionally, small-scale food production would have enabled Hammondville residents to retain a larger portion of their income, rather than spending at the company store.

\section{SITE DESCRIPTIONS}

Faunal remains were recovered from two working-class residential sites in the village of Hammondville (Fig. 9). The first site is known as the 'Stanton/O'Rourke' double house. From the 1870 s to about 1890 the Stanton family, who were first generation Irish immigrants, lived in the west side of the house. Patrick Stanton was a blacksmith and he and his wife, Bridget, had seven children. During the late 1870s and early 1880s the east side of the house was most likely occupied by the American Bigelow family, though documentary evidence is somewhat unclear. Sometime in the early 1880 s another first generation Irish family, the O'Rourkes, moved into the east side of the house and remained there into the 1890s. The second site, known as 'Long Row 2' was one of three large row houses built at Hammondville. These structures were 100 feet long and were de- signed to house five families (Northey 1942), though it is likely that they often held more. A newspaper article states that a New York State census worker recorded 15 families living in Long Row 2 in 1875 (Essex County Republican 1875). It has not been possible to determine which specific families lived in Long Row 2, although they were almost certainly working-class.

\section{METHODS}

The faunal assemblages discussed here were recovered as part of a systematic and judgmental sampling strategy in the back and side yard areas of Long Row 2 and the Stanton O'Rourke double house. A $5 \mathrm{~m}^{2}$ grid with $50 \mathrm{~cm}^{2}$ test units was excavated in the yard area of each structure. Fieldwork identified one large midden in the yard of each structure: a shallow sheet midden in the rear yard at Long Row 2 and a deeper midden located just west of the Stanton-O'Rourke house, where residents threw garbage over a small rock ledge. Three $1 \mathrm{~m}^{2}$ units were excavated in each of these areas and the majority of faunal remains discussed here derive from these contexts. All units were excavated in $5 \mathrm{~cm}$ levels. Soils from the $50 \mathrm{~cm}^{2}$ units were screened through $1 / 4$ " mesh and the soils from the $1 \mathrm{~m}^{2}$ units were screened through $1 / 8$ " mesh. The methods of zooarchaeological analysis are described in detail in Sportman (2011: 207-210). In order to compare the assemblages with the company store inventory, the relative abundance of edible species from each assemblage was calculated.

\section{RESULTS}

The Long Row 2 faunal assemblage had a NISP (Number of Identified Specimens Present) of 284 and the Stanton-O'Rourke faunal assemblage had a NISP of 569; domesticated animals dominate the faunal assemblages from both sites (Table 3). Catthe (Bos taurus) were the most common species in each assemblage, clearly reflecting the emphasis on beef in the company store inventory. Much smaller quantities of pig (Sus scrofa) and sheep/goat (caprine) bones were also recovered at each site. However, the relative abundance of each of these species is likely under-represented. Numerous specimens from each site were identifiable only as 'medium mammal' (NISP=186 at Stanton-O'Rourke; NISP=88 


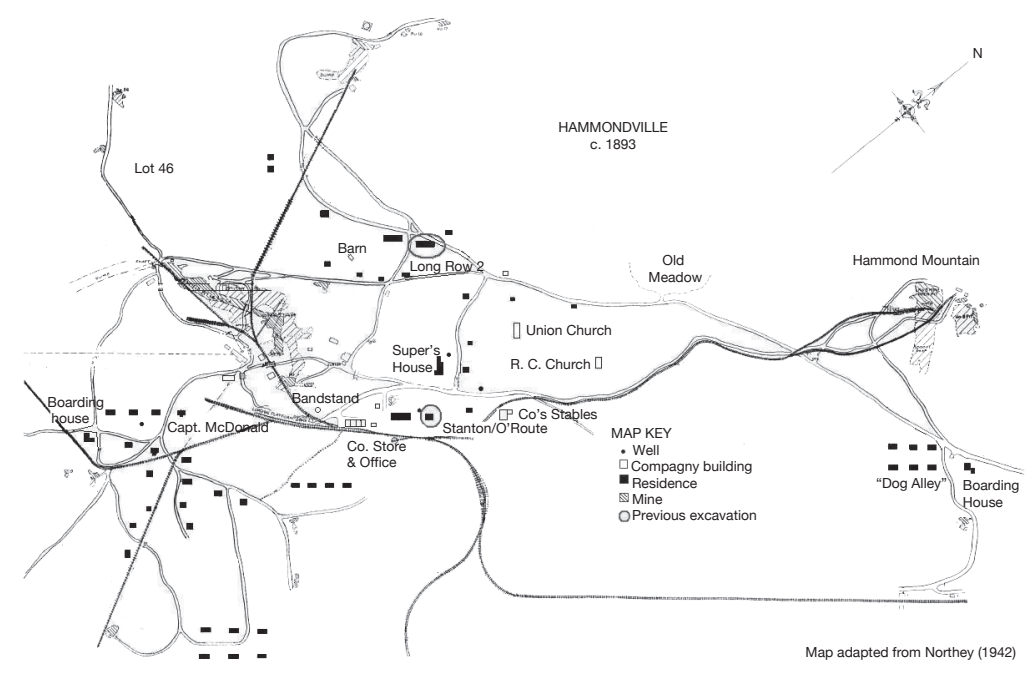

FIG. 9. - Map of Hammondville showing the location of Long Row 2 and the Stanton-O'Rourke double house (adapted from Northey 1942).

at Long Row 2). Pig and sheep almost certainly comprise the majority of these specimens, which reflect the large numbers of rib and vertebrae fragments that were recovered at each site. These bones, when fragmented, are very difficult to identify to species, and as a result they were simply assigned to a general size category and not included in Fig. 10. The remains of turkey (Meleagris gallopavo) were also recovered at both sites. Turkey is listed in the company store records, but it was only available at the store during the Christmas season. It is a species that was locally available and may have either been purchased at the company store or hunted.

Although both assemblages were dominated by foods most likely purchased at the company store, there is also evidence that people supplemented their diets through hunting, fishing and raising small numbers of domesticated animals. A small number of wild animal remains were also recovered in each assemblage. At the 'Stanton-O'Rourke' house, the assemblage included rabbit (Sylvilagus floridanus), hare (cf. Lepus americanus) and pigeon (Columbidae), as well as several specimens only identifiable as 'small mammal' and not included in Figure 10. The Long Row 2 assemblage included small numbers of deer (Odocoileus virginianus), rabbit (Sylvilagus floridanus), duck (Anas sp.) and

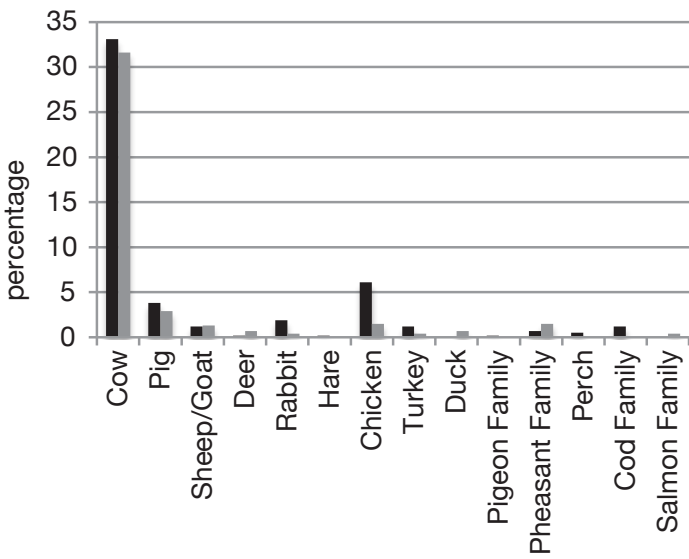

Stanton-O'Rourke

Long Row 2

FIG. 10. - Relative abundance of edible taxa at Long Row 2 and Stanton-O'Rourke.

also 'small mammal'. Rabbit specimens from both assemblages exhibit evidence of butchery and are therefore included among food animals. One duck specimen also exhibits signs of butchery. The single pigeon bone is not butchered, but it was recovered along with the remains of food animals and likely 
also represents food. The presence of these species suggests that Hammondville residents sometimes supplemented their diets with locally hunted game.

Chicken (Gallus gallus) remains were also recovered at each site. Store records indicate that the Hammondville company store did not sell chicken. It is likely, therefore, that some residents raised chickens in their yards for meat and eggs. The idea that people in the village raised small numbers of domesticated animals is also supported by an historic account which indicated that the C.P.I.Co. provided a small plot of pasturage for the villagers who owned a cow (Bixby 1911).

Finally, small numbers of both local and ocean fish remains were also present in the assemblages. These species are likely underrepresented due to preservation biases. The Stanton-O'Rourke assemblage included perch (Perca sp.) and cod (Gadidae). Perch is abundant in local waters, but cod, which had to be imported from the coast, was likely purchased. At Long Row 2 the assemblage included vertebrae from Salmonidae. This family includes salmon and trout. Salmon would have been purchased, but as none are listed in the company store inventory, they would have to have been purchased outside of the village. Trout, on the other hand, are abundant in local waters in the Adirondack region of New York. A documentary source even indicates that the C.P.I.Co. had a nearby pond stocked with 'salmon trout' in the 1870s (Bixby 1991: 209), presumably to provide a leisure activity for company labourers.

The relative abundance data from the Long Row 2 and Stanton-O'Rourke sites suggests while Hammondville residents relied heavily on the company store for their subsistence needs they also supplemented the foods they purchased from the company store by hunting, fishing and raising small numbers of domesticated animals. For some, hunting and fishing may have simply been leisure activities. However, such practices would have also facilitated the procurement of foods that were not available at the store. Hunting, fishing and raising small numbers of domesticated animals would also have enabled Hammondville residents to reduce the proportion of their wages returned to the C.P.I.Co. through purchases from the company store.

\section{CONCLUSIONS}

The availability of company store ledgers and zooarchaeological data facilitate a holistic examination of dietary variability and ethnic foodways among Hammondville's diverse population. Company store records provide detailed information about the types and cuts of meat available at the company store. Some of these items, such as boneless cold cuts of meat, leave no traces in the archaeological record. Without store records, there would be no way to know that such foods were included in peoples' diets at Hammondville. Store records permit in-depth analyses of the purchasing patterns of individual households and larger ethnic groups in the village, which sheds light on food preferences and dietary differences that would be very difficult to recognise archaeologically. However, the records provide an incomplete picture of food procurement systems and overall diet. Faunal remains recovered from domestic sites in the village suggest that Hammondville residents also procured food through hunting, fishing and raising small numbers of domesticated animals. In isolation, either type of data sheds light upon food and diet in the village, but the combination of both lines of evidence provides a clearer, more complete picture of past activities.

The data presented here suggest that while Hammondville residents relied heavily on the C.P.I.Co.'s store for their subsistence needs, individuals and families from different backgrounds worked within the structures of company control to construct diets that both met their subsistence needs and expressed their cultural identities. They accomplished this in two ways. First, people adapted their diets and foodways to make the most of the limited company store inventory. Although people could not always rely on a diet of preferred or traditional foods, they went out of their way to purchase such items when they were available. For example, despite the dominance of beef in the store inventory, French Canadians in the village continued to rely heavily on pork, English consumers purchased mutton whenever it was available and Swedish residents purchased relatively large quantities of headcheese. Second, many Hammondville residents also supplemented their diets through fishing, hunting and 
raising small numbers of domesticated animals. This enabled them both to procure foods not available at the company store and reduce the amount of their income returned to the C.P.I.Co. through food purchases.

Although people clearly strove to maintain aspects of their traditional foodways when possible, the data also suggest that recent immigrant groups at Hammondville began to construct new foodways that incorporated American staples, like beef. While they did not give up their cultural traditions surrounding food, they adapted them to an unfamiliar physical and cultural environment, creating new meaning around food as they incorporated different items into their diets. Given the symbolic nature of food and its importance in cultural systems, such practices were likely key aspects in the performance of identity among villagers from different backgrounds.

\section{Acknowledgements}

I would like to thank the members of my dissertation committee - Kevin McBride, Natalie Munro and David Landon - for their help and advice, as well as the anonymous reviewers who offered encouragement and useful comments on an earlier draft of this paper. I would also like to thank Richard Thomas for organising the conference session and for his work in organising and editing this volume. Finally, I would like to thank the graduate and undergraduate students from the University of Connecticut who volunteered their time to help with the fieldwork for this project, which was funded by two Graduate Summer Research Fellowships from the University of Connecticut and a grant from the Society for Industrial Archaeology.

\section{REFERENCES}

ANON 1897._ Swedish-English Cookbook. The EngbergHolmberg Publishing Co., Chicago.

BEETON I. 1861. - Beeton's Book of Household Management. S.O. Beeton, London.

BIXBY G. 1911. — The iron ore industry of Lake Champlain. Proceedings of the New York State Historical Association 10: 171-237.

Brault G. 1986. - The French Canadian Heritage in New
England. University Press of New England, Hanover. BUREAU OF STATISTICS OF LABOR 1886. - Seventeenth Annual Report of the Bureau of Statistics of Labor. Public document no. 15. Wright \& Potter Printing, Boston. CAMP C. 1989._-American Foodways: What, When, Why and How We Eat in America. August House Publishers, Little Rock.

CraWford M. 1995. - Building the Working Man's Paradise: the Design of American Company Towns. Verso, London.

DINER H. 2002. - Hungering for America: Italian, Irish and Jewish Foodways in the Age of Migration. Harvard University Press, Boston.

Elizabethtown Post and GazeTte 1896. — Local happenings in Crown Point, NY, 8 December 1896, Elizabethtown.

Elizabethtown Post and GazetTe 1900a. — Local happenings in Crown Point, NY, 8 March 1900, Elizabethtown.

ElizabeThtown Post And GazetTe 1900b. — Local happenings in Crown Point, NY, 29 March 1900, Elizabethtown.

ESSEX COUNTY REPUBLICAN 1875. — Local happenings in Crown Point Centre, NY, 10 August 1875, Keeseville.

GARNER J. 1992. - The Company Town: Architecture and Society in the Early Industrial Age. Oxford University Press, Oxford.

Gradwohl D. \& Osborn N. 1984. - Exploring Buried Buxton: Archaeology of an Abandoned Iowa Coal Mining Town With a Large Black Population. Iowa State University Press, Ames.

Hammond J. 1884. - Statement to the Board of Directors of the Crown Point Iron Company, 14 March. Transcription on File at the Penfield Museum, Ironville.

Henderson M.1877. — Practical Cooking and Dinner Giving. Harper \& Brothers, New York.

HuELSBECK D. 1991. - Faunal remains and consumer behavior: what is being measured? Historical Archaeology 25: 62-76.

JANOWITZ M. F. 1993. — Indian corn and Dutch pots: seventeenth-century foodways in New Amsterdam, New York. Historical Archaeology 27: 6-24.

Kaplan A.1986. — Minnesota Ethnic Food Book. Minnesota Historical Society Press, St. Paul.

LARSON E. \& BARTON H. A. 1987. — Aunt Ellen remembers. Swedish-American Historical Quarterly 38: 117-31.

Lightfoot K., Martinez A. \& Schiff A. M. 1998. Daily practice and material culture in pluralistic social settings: an archaeological study of culture change and persistence from Fort Ross, California. American Antiquity 63: 199-122.

MCBRIDE K. 2007. - Transformation by degree: eighteenth century Native American land use. In J. Campisi (ed.), Eighteenth Century Native Communities of Southern New England in the Colonial Context. Mashantucket 
Pequot Museum and Research Center Occasional Paper No. 1, Mashantucket: 35-57.

MCGUIRE R.1991. - Building power in the cultural landscape of Broome County, New York 1880-1940. In R. PAYNTER \& R. MCGuire (eds), The Archaeology of Inequality. Blackwell Press, Oxford: 102-124.

MCKeE L.1987. - Delineating ethnicity from the garbage of early Virginians: Faunal remains from the Kingsmill plantation slave quarter. American Archaeology 6: 31-39.

Milne C. \& Crabtree P. J. 2001. - Prostitutes, a rabbi and a carpenter - dinner at the Five Points in the 1830s. Historical Archaeology 35: 31-48.

Miner H.1939. - St. Denis, a French-Canadian Parish. University of Chicago Press, Chicago.

MrozowsKI S.1991. - Landscapes of inequality. In R. MCGuire AND R. PAYNTER (eds) Archaeology of Inequality Blackwell Press, Oxford: 79-101.

NortheY W. C. 1940. — Letter to E. Eugene Barker. Ticonderoga Sentinel, August 1962.

NorTHEY W. C. 1942._- Map of Hammondville ca. 1893, created at the request of Elmer Eugene Barker. Copy on file at the Ticonderoga Historical Society, Ticonderoga. Map archived at the Penfield Foundation, Ironville.

Plattsburgh Sentinel 1874. — Local happenings in
Crown Point, NY, 12 February, 1874, Plattsburgh. Pope C. 1971. - Hammondville: Essex County ghost Town. York State Tradition 25: 33-44.

REITZ E. 1991. - Animal use and culture change in Spanish Florida. In P. Crabtree \& K. Ryan (eds), Animal Use and Culture Change. MASCA Research Papers in Science and Archaeology, Supplement to Vol. 8. University of Pennsylvania Museum, Philadelphia: 62-78.

SCHULz P. \& GUST S. 1983. - Faunal remains and social status in 19th century Sacramento. Historical Archaeology 17: 44-53.

Spencer C. 2003. - British Food: An Extraordinary Thousand Years of History. Columbia University Press, New York.

SpORTMAN S. 2011. - Halcyon Days: the Historical Archaeology of Identity and Community at Hammondville, New York, 1870-1900. Doctoral Dissertation, Department of Anthropology, University of Connecticut, Storrs.

Ticonderoga SENTINEL 1874 - Local happenings in Hammondville, NY, 11 April 1874, Ticonderoga.

United States Bureau of the Census 1880. - Population of the United States, 1880. U.S. Department of the Interior, Washington, DC. 